Original article

\title{
Transplacental transmission of bovine tick-borne pathogens: Frequency, co-infections and fatal neonatal anaplasmosis in a region of enzootic stability in the northeast of Brazil
}

\author{
Sonia Carmen Lopo Costa ${ }^{a}$, Vanessa Carvalho Sampaio de Magalhães ${ }^{a}$, \\ Uillians Volkart de Oliveira ${ }^{\mathrm{b}}$, Fábio Santos Carvalho ${ }^{\mathrm{a}}$, Clebson Pereira de Almeida ${ }^{a}$, \\ Rosangela Zacarias Machado ${ }^{\mathrm{c}}$, Alexandre Dias Munhoz ${ }^{\mathrm{a}, *}$ \\ a Department of Agricultural and Environmental Sciences, Universidade Estadual de Santa Cruz (UESC), Campus Soane Nazaré de Andrade, \\ Rod. Jorge Amado, Km 16, Salobrinho, Ilhéus, Bahia 45662-900, Brazil \\ ${ }^{\mathrm{b}}$ Faculty of Social and Applied Sciences (FACISA), Rodovia BR 101, $1130 \mathrm{~km} \mathrm{808,} \mathrm{Santo} \mathrm{Antônio} \mathrm{Monte,} \mathrm{Itamaraju,} \mathrm{Bahia} \mathrm{45836-000,} \mathrm{Brazil}$ \\ ' Departmentof Animal Pathology, Universidade Estadual Julio Mesquita Filho, UNESP/Jaboticabal, Rod. Paulo Castelanne s/n, Jaboticabal, \\ São Paulo 4884-900, Brazil
}

\section{A R T I C L E I N F O}

\section{Article history:}

Received 12 November 2014

Received in revised form 30 October 2015

Accepted 5 November 2015

Available online 10 November 2015

\section{Keywords:}

Babesiosis

Anaplasmosis

Cattle

Transplacental transmission

\begin{abstract}
A B S T R A C T
Bovine tick-borne disease (TBD) constitutes a worldwide group of diseases that result in great losses for dairy and beef cattle. With regard to the epidemiological profile of the diseases, the importance of transplacental transmission is still not very well understood. The aim of this study was to determine the transplacental transmission of TBD agents (Anaplasma marginale, Babesia bovis and B. bigemina) in a herd of dairy cattle that had been naturally infected in an area of enzootic stability in northeastern Brazil. Blood for serology of the three agents was collected from cows within 120 days of gestation and serology, haemogram and nPCR assays were performed after birth. Blood was collected from the calves within $3 \mathrm{~h}$ of birth, and haemogram and nPCR assays were performed in all animals. Pre-colostrum serology was achieved in 34 animals. The Student's $t$-test was used to compare the haemogram results between animals that were positive and negative for the haemoparasites. The cows were seropositive for all agents in at least one of the examinations. We detected 15 cases of vertical transmission of A. marginale, 4 of $B$. bovis and 2 of $B$. bigemina in the 60 cows. In infected animals, co-infection was detected for $A$. marginale and $B$. bovis in 1 of 60 calves, and a triple infection was detected in one other calf. Fatal neonatal anaplasmosis was observed in 1 of 15 calves, in which death occurred within $24 \mathrm{~h}$ of birth. From the results, we concluded that transplacental transmission of TBD agents occurs, including in cases of co- and triple-infection. Such transplacental transmission can cause neonatal death, increasing the importance of this form of epidemiological transmission and suggesting its role as a cause of undiagnosed neonatal death.
\end{abstract}

(c) 2015 Elsevier GmbH. All rights reserved.

\section{Introduction}

Bovine tick-borne diseases (TBDs) are caused in Brazil mainly by Babesia bovis, B. bigemina and Anaplasma marginale, which occur throughout the tropical, subtropical and temperate areas of the world (Guglielmone, 1995; Echaide et al., 1998; Tembue et al., 2011; Ait-Hamou et al., 2012). As TBD agents are simultaneously present in most regions of enzootic stability or instability (Barros et al., 2005; Atif et al., 2012; Shebish et al., 2012; Brito et al., 2013; Mtshali

\footnotetext{
* Corresponding author.

E-mail address: munhoz@uesc.br (A.D. Munhoz).
}

et al., 2013), they are a limiting factor in animal husbandry development in these locations (De Vos et al., 1976; Kessler, 2001; Kocan et al., 2003, 2010; Aubry and Geale, 2011).

The main means of transmission in Brazil is the tick Rhipicephalus microplus, direct transmission by fomites (needles, surgical instruments and piercing objects), haematophagous Diptera (Tabanidae, Culicidae and Muscidae) (Brito et al., 2010; Reinbold et al., 2010; Aubry and Geale, 2011), and transplacental pathways (Neitz, 1956; Potgieter and Van Rensburg, 1987; Ribeiro et al., 1995; Grau et al., 2013; Santarosa et al., 2013); however, little is known about the real contribution of the transplacental pathways in the epidemiology of TBDs (Kessler, 2001; Kocan et al., 2003; Aubry and Geale, 2011). 
The results of natural transplacental transmissions in several studies differ, and report absent (Piercy, 1956; Kuttler et al., 1962), low (Passos and Lima, 1984; Ribeiro et al., 1995) or moderate transmission (Maldonado et al., 2012; Silva et al., 2014) rates, which lead to the hypothesis that the importance of this transmission pathway may vary by region, depending on the climate characteristics, the cattle, and the presence of vectors, or it may be based on the genetic variability of the agent.

The transplacental transmission of $A$. marginale is the most common, being described extensively in experimental studies, including longitudinal studies (Norton et al., 1983; Potgieter and Van Rensburg, 1987; Ribeiro et al., 1995; Pypers et al., 2011; Maldonado et al., 2012; Grau et al., 2013; Silva and Fonseca, 2014; Silva et al., 2015). It mainly occurs between the second and third trimesters of pregnancy (Fowler and Swift, 1975; Swift and Paumer, 1976, 1978; Zaugg and Kuttler, 1984; Zaugg, 1985; Potgieter and Van Rensburg, 1987; Ribeiro et al., 1995). The vertical transmission of $B$. bovis has been reported, in most cases, as isolated cases (Neitz, 1956; De Vos et al., 1976; Barbosa et al., 1994; Bracarense et al., 2001; Osaki et al., 2002; Yeruham et al., 2003; Santarosa et al., 2013). Reports of transplacental transmission of $B$. bigemina were only found in older studies (Zolotareff, 1936, Roux, 1939 cited by Neitz, 1956; Atwell, 1975).

The death of calves infected transplacentally by naturally infected cows has been previously reported (De Vos et al., 1976; Paine and Miller, 1977; Norton et al., 1983; Barbosa et al., 1994; Bracarense et al., 2001; Pypers et al., 2011; Santarosa et al., 2013), and these reports characterize this epidemiologically important transmission pathway, whilst also improving estimates of economic losses due to infection.

The livestock agribusiness world is particularly affected by TBDs because more than 1.2 billion heads are at risk for infection and developing disease (Bock et al., 2004). It is estimated that in the next decade, TBDs will cause losses in the order of $\$ 282$ million in Australia as a direct consequence of the infections when considering miscarriages, reductions in milk production and weight gain, deaths and the costs of prevention and treatment (Gohil et al., 2013). These estimates may increase due to the continuing increase in the distribution of the infections, as a function of the intense transportation of asymptomatic animals and the subsequent transmission to susceptible individuals, as well as the effects of global warming, which significantly alters the distribution of vectors and parasites throughout the world (Kocan et al., 2010).

On the basis of the above and in view of the great damage caused by anaplasmosis and babesiosis in global livestock, this study aims to determine the frequency of transplacental transmission of TBD agents and reports one case of fatal neonatal anaplasmosis in a naturally infected, crossbred herd occurring in an endemic region of zoonotic stability in northeastern Brazil.

\section{Materials and methods}

\subsection{Area of study}

The study was conducted from October 2010 to June 2011 on a property with a history of clinical babesiosis and anaplasmosis cases in young animals. The property is in the municipality of Ibicaraí in a micro-region of Itabuna-Ilhéus in the state of Bahia in Brazil's northeast region (14 $51^{\prime} 54^{\prime \prime}$ South and $39^{\circ} 35^{\prime} 16^{\prime \prime}$ West at an altitude of $270 \mathrm{M}$ ). The study area is in the Atlantic forest area. The annual average rainfall is $1445 \mathrm{~mm}$, with a relative humidity of $80 \%$ and a temperature of $24^{\circ} \mathrm{C}$ (MAPA, 2010).

The selected property has 135 acres and 350 animals. The herd was composed of crossbred cattle (1/4 Bos taurus indicus combined with $3 / 4$ Bos t. taurus to $1 / 4$ Bos t. taurus combined with $3 / 4$ Bos $t$. indicus) that are maintained in a semi-intensive system. The daily production of milk from 110 lactating cows is 12001 , obtained from two daily milkings using a closed system, mechanical milking machine. Nutrition is based on a rotational grazing system, with mineral supplementation offered ad libitum. The adult animals received concentrated supplements composed of corn, soybeans and urea once a day, while the calves were fed milk and a concentrate composed of corn and soybeans. Ectoparasite control was carried out strategically by spraying the whole herd at intervals of 21 days with ectoparasiticides indicated by a tick-susceptibility bioassay.

\subsection{Sample collection and processing}

Sixty pregnant cows with an average age of 7.4 years $( \pm 1.7$ years) were included in the study sample and had their initial blood collection within the first 120 days of gestation for TBD serological diagnoses. These cows and their calves had their blood collected at the time of the calf's delivery, or in some cases, a maximum of $3 \mathrm{~h}$ after birth. The blood of these animals was conditioned in tubes with an anticoagulant (EDTA) and without an anticoagulant for performing the haemogram, molecular parasitic identification, the determination of the calves' parasitemia by blood smear and the serology of the cows and 34 calves that had not ingested colostrum, confirmed by the low concentration of the gamma-glutamyl transferase serum, as described by Perino et al. (1993).

The haemogram was carried out in an automatic ABX Vet counter (Horiba, São Paulo, Brazil). The total plasma protein values were obtained using manual refractometry. The parasitemia was estimated by counting the number of parasitized erythrocytes in a sample size of 1000 , the result was then expressed as a percentage. After the haemogram, whole blood and serum aliquots were placed in $2.0 \mathrm{~mL}$ sterile plastic cryotubes free of DNase and RNase, in duplicate, and stored at $-20^{\circ} \mathrm{C}$.

\subsection{Genomic DNA extraction, $P C R$ and nested-PCR ( $n P C R)$ for the diagnosis of Anaplasma marginale, Babesia bigemina and Babesia bovis}

The extraction of DNA from blood samples was performed using the QIAamp DNA Blood mini Kit (QIAGEN, Hilden, Germany), following the manufacturer's recommendations. The extracted DNA was kept at $-20^{\circ} \mathrm{C}$. A Nested-Polymerase Chain Reaction (nPCR) was performed independently for each agent using the primers described by Lew et al. (2002), Suarez et al. (1991) and Terkawi et al. (2011) as presented in Table 1.

Babesia bovis was detected using primers described by Suarez et al. (1991). The reactions were performed using a final volume of $25 \mu \mathrm{L}$, with $5 \mu \mathrm{L}$ of DNA template, reaction buffer $(5 \times)$,

Table 1

The primers used in PCR (1st reaction) and $\mathrm{nPCR}$ (2nd reaction) for the identification of the transplacental transmission of tick-borne disease agents in a naturally infected crossbred herd in Ibicaraí in the northeast of Brazil.

\begin{tabular}{|c|c|c|c|}
\hline Agent & Sequence of oligonucleotides $\left(5^{\prime}-3^{\prime}\right)$ & Reaction & Reference \\
\hline Babesia bovis & $\begin{array}{l}\text { CACGAGGAAGGAACTACCGATGTTGA } \\
\text { CCAAGGAGCTTCAACGTACGAGGTCA } \\
\text { TCAACAAGGTACTCTATATGGCTACC } \\
\text { CTACCGAGCAGAACCTTCTTCACCAT }\end{array}$ & $1^{\mathrm{a}}$ & $\begin{array}{l}\text { Suarez et al. } \\
\text { (1991) }\end{array}$ \\
\hline $\begin{array}{l}\text { Babesia } \\
\text { bigemina }\end{array}$ & $\begin{array}{l}\text { GAGTCTGCCAAATCCTTAC } \\
\text { TCCTCTACAGCTGCTTCG } \\
\text { AGCTTGCTTTCACAACTCGCC } \\
\text { TTGGTGCTTTGACCGACGACAT }\end{array}$ & $1^{\mathrm{a}}$ & $\begin{array}{l}\text { Terkawi et al. } \\
\text { (2011) }\end{array}$ \\
\hline $\begin{array}{l}\text { Anaplasma } \\
\text { marginale }\end{array}$ & $\begin{array}{l}\text { TGTGCTTATGGCAGACATTTCC } \\
\text { AAACCTTGTAGCCCCAACTTATCC } \\
\text { TGTGCTTATGGCAGACATTTCC } \\
\text { TCACGGTCAAAACCTTTGCTTACC }\end{array}$ & $1^{\mathrm{a}}$ & $\begin{array}{l}\text { Lew et al. } \\
\text { (2002) }\end{array}$ \\
\hline
\end{tabular}


$3 \mathrm{mM}$ magnesium chloride, $200 \mu \mathrm{M}$ of each dNTP, $1 \mu \mathrm{M}$ of each external primer, and $1.25 \mathrm{U}$ of Taq Polymerase supplemented with ultra-pure water. The tubes were briefly centrifuged and were subsequently placed in a MJ96G thermalcycler (Biocycler Technology Co., Hangzhou, Zhejiang), which performed an initial denaturation at $95^{\circ} \mathrm{C}$ for $5 \mathrm{~min}$, followed by 35 cycles of $1 \mathrm{~min}$ at $94^{\circ} \mathrm{C}, 55^{\circ} \mathrm{C}$ for $1 \mathrm{~min}$, an extension at $72^{\circ} \mathrm{C}$ for $40 \mathrm{~s}$, and a final extension at $72^{\circ} \mathrm{C}$ for $5 \mathrm{~min}$. For the nPCR, the same volume and mix concentrations were used in addition to $2 \mu \mathrm{L}$ of the PCR product resulting from each sample. The thermocycling conditions used were the same as those used in the PCR assay, except with the change of the annealing temperature to $65^{\circ} \mathrm{C}$, the protocol used was in accordance with that described by Amorim et al. (2014), with modifications.

To assess $A$. marginale, the reactions were performed using primers described by Lew et al. (2002), using a final volume $12.5 \mu \mathrm{L}$, $2.5 \mu \mathrm{L}$ of DNA template, reaction buffer $(10 \times), 1.5 \mathrm{mM}$ magnesium chloride, $200 \mu \mathrm{M}$ of each dNTP, $1 \mu \mathrm{M}$ of each external primer, and $1.25 \mathrm{U}$ of Taq polymerase supplemented with ultra-pure water. The tubes were briefly centrifuged and subsequently placed in a thermocycler MJ96G (Biocycler Technology Co., Hangzhou, Zhejiang) which performed an initial denaturation at $95^{\circ} \mathrm{C}$ for $15 \mathrm{~min}$, followed by 40 cycles of $30 \mathrm{~s}$ at $94^{\circ} \mathrm{C}$ of denaturation, annealing at $55^{\circ} \mathrm{C}$ for $1 \mathrm{~min}$ with an extension at $72{ }^{\circ} \mathrm{C}$ for $1.5 \mathrm{~min}$ and a final extension at $72^{\circ} \mathrm{C}$ for $7 \mathrm{~min}$. For the nPCR assay, we used the same concentrations and final volume of the mix. The thermocycling conditions were the same except that the annealing temperature was changed to $60^{\circ} \mathrm{C}$ for $1 \mathrm{~min}$, in accordance with Baêta et al. (2014).

To assess $B$. bigemina, the reactions were performed using the mix concentration, thermocycling conditions and primers described by Terkawi et al. (2011), using a final volume of $10 \mu \mathrm{L}$ with $1 \mu$ L of template DNA, reaction buffer $(10 \times), 1.5 \mathrm{mM}$ of magnesium chloride, $200 \mu \mathrm{M}$ each of the dNTP, $1 \mu \mathrm{M}$ each of the external primer, and $0.5 \mathrm{U}$ of Taq polymerase supplemented with ultra-pure water. The tubes were briefly subjected to centrifugation and subsequently placed in a thermocycler MJ96G (Biocycler Technology Co., Hangzhou, Zhejiang), which performed an initial denaturation at $95^{\circ} \mathrm{C}$ for $5 \mathrm{~min}$, followed by 35 cycles of $1 \mathrm{~min}$ at $94^{\circ} \mathrm{C}$ for denaturation, annealing at $55^{\circ} \mathrm{C}$ for $1 \mathrm{~min}$ with an extension at $72^{\circ} \mathrm{C}$ for $1 \mathrm{~min}$ and a final extension at $72^{\circ} \mathrm{C}$ for $10 \mathrm{~min}$. The $\mathrm{nPCR}$ assay used the same final volume, concentrations and thermal cycling conditions. All of the positive controls ( $A$. marginale, B. bigemina and $B$. bovis) were from Amorim et al. (2014) and ultra-pure water was used for the negative controls.

Electrophoresis of the products was performed on a $2 \%$ agarose gel in a TAE running buffer ( $40 \mathrm{mM}$ Tris-acetate and $2 \mathrm{mM}$ EDTA with a $\mathrm{pH}$ of 8.0). The run was made at $80 \mathrm{~V}$ and $180 \mathrm{~mA}$ for a period of $30 \mathrm{~min}$. The gel was subsequently stained with ethidium bromide $(0.5 \mu \mathrm{g} / \mathrm{mL})$. The amplified products were estimated using a base pair pattern (1 Kb Plus DNA Ladder-Invitrogen, Carlsbad, CA, USA). The amplified product visualizations were held in an ultraviolet transilluminator (UV) L.PIX (Loccus Biotecnologia, São Paulo - SP) and photographed by a coupled image analyser.

\subsection{Serology}

The serology was performed using the indirect ELISA method described by Machado et al. (1997). The reaction reading was made in a microplate reader (Imulon ${ }^{\circledR}$ Dynatech Laboratories Inc.) at a wavelength of $405 \mu \mathrm{m}$. The antigens used in this experiment were purified according to the technique recommended by Machado et al. (1997), from isolates of A. marginale, B. bovis and B. bigemina and were kept in the immunoparasitology laboratory at the Faculty of Agronomical and Veterinary Sciences of UNESP (Jaboticabal-SP). Serum samples that had an optical density (OD) two and a half times those of the negative controls were considered positive.

\subsection{Statistical analysis}

The Student's $t$-test, with a significance level of $95 \%$, was used to analyze the results of the haemogram.

\section{Results}

The A. marginale serology performed within the first 120 days of gestation demonstrated 52 positive cows out of 60 , while 59 of 60 cows were positive during birth. Of these, 27 were also positive by nPCR. Vertical transmission detected by a molecular method was observed in 10 of 60 calves. The pre-colostral serology was positive in 9 of 34 calves, and in combination with the molecular and serological results, 15 of 60 calves received a positive diagnosis, of which 4 of 15 were found to be positive by both serology and nPCR. All of the calves diagnosed as positive were born to mothers positive by nPCR or serology at the time of birth (Table 2).

All the cows were $B$. bovis positive according to the serology tests at the time of the first collection, and 58 of 60 were positive at the time of birth. The molecular diagnosis indicated a positivity in 42 of 60 cows. Transplacental transmission was observed in 3 of 60 calves, as assessed by nPCR, and 1 of 34 calves, as assessed by ELISA. Transplacental transmission of $B$. bovis was therefore found in 4 of 60 calves; all positive new-borns were asymptomatic and were born to cows that were positive (Table 2).

Fifty-eight of 60 cows had positive serology for $B$. bigemina at the time of the first collection, 52 of 60 were positive at the time of birth and 21 of 60 were diagnosed positive by nPCR. At birth, 2 of 60 calves were found to be positive by nPCR.

Co-infection with $A$. marginale and $B$. bovis was detected in 1 of 60 calves, and a triple infection was found in one calf, all were asymptomatic.

Only 3 of 60 calves were positive by blood smear, all 3 showing A. marginale. The observed parasitemia varied between 0.1 and $2 \%$. The haematimetric parameters assessed in calves and cows showed reductions in the packed cell volume and haemoglobin concentration of calves that were haemoparasite positive $(p<0.05)$.

Among the calves followed in this study, three were born apathetic with hypothermia and pale mucous membranes. One of them showed mild icterus, evidenced in the vaginal mucosa. Each of these calves died within $24 \mathrm{~h}$ of birth. These three calves were positive only for $A$. marginale as assessed by nPCR. These animals presented with packed cell volumes of $15 \%, 14 \%$ and $20 \%$, with A. marginale parasite levels of $0.4 \%, 2 \%$ and $0.1 \%$, respectively. The deliveries occurred within the expected time, with no signs of distortion. All of the other calves studied presented with normal clinical parameters at birth. Additional tests were conducted for the differential diagnosis in material taken from the calves that died. Thus, the seroneutralization test was performed for the diagnosis of Infectious Bovine Rhinotracheitis (IBR), and Bovine Viral Diarrhea Virus (BVDV), the microagglutination test was performed for the diagnosis of leptospirosis (serotypes of Leptospirainterrogans: L. icterohaemorrhagiae, L. canicola, L. pomona, L. hardjo, L. tarassovi, L. bratislava, L. grippotyphosa, L. hebdomadis, $L$. wolffi), the rose bengal plate agglutination test was performed for the diagnosis of Brucella abortus, and the immunofluorescent antibody test was performed for the diagnosis of Neospora caninum, and PCR was performed to assess the calves' leptospirosis status. The three calves were negative by serology for leptospirosis, IBR and B. abortus. Two were positive by serology for BVDV and positive by PCR for leptospirosis, and one was positive by serology for $N$. caninum. One calf was positive only for $A$. marginale, with a parasitaemia of $0.4 \%$ and a packed cell volume of $15 \%$. This calf received a presumptive diagnosis of neonatal fatal anaplasmosis. 
Table 2

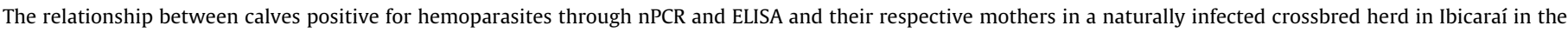
northeast of Brazil.

\begin{tabular}{|c|c|c|c|c|c|c|c|c|c|}
\hline \multirow[t]{2}{*}{ Calve } & \multicolumn{3}{|c|}{ Calf nPCR/ELISA } & \multicolumn{3}{|c|}{ nPCR Cow } & \multicolumn{3}{|c|}{ ELISA Cow (Initial/Final) } \\
\hline & A.m ${ }^{a}$ & B.bo $^{\mathrm{b}}$ & B.bic & A.m & B.bi & B.bo & A.m & B.bi & B.bo \\
\hline $\mathrm{F} 1$ & $-1+$ & $-1-$ & $-1-$ & - & + & + & $+/+$ & $+/+$ & $+/+$ \\
\hline F3 & $-1+$ & $-1-$ & $-1-$ & - & - & + & $+1+$ & $+1+$ & $+1+$ \\
\hline $\mathrm{H} 1$ & $-1+$ & $-1-$ & $-1-$ & + & - & - & $+/+$ & $+/+$ & $+/+$ \\
\hline H9 & $-1+$ & $-1-$ & $-1-$ & + & - & - & $+1+$ & $+1+$ & $+1+$ \\
\hline J5 & $-1+$ & $-1-$ & $-1-$ & - & + & + & $-1+$ & $+1+$ & $+/+$ \\
\hline C9 & $+/ \mathrm{su}^{\mathrm{d}}$ & $-/ \mathrm{su}$ & $-/$ su & - & - & + & $+1-$ & $+1-$ & $+1-$ \\
\hline $\mathrm{D} 1^{\mathrm{e}}$ & $+1+$ & $-1-$ & $-1-$ & + & - & - & $+1+$ & $+1+$ & $+/+$ \\
\hline D5 & $-/ \mathrm{su}$ & $+/ \mathrm{su}$ & $-/ \mathrm{su}$ & - & - & + & $+1+$ & $+1+$ & $+1+$ \\
\hline G1 & $+/ \mathrm{su}$ & $-/ \mathrm{su}$ & $-/ \mathrm{su}$ & + & - & + & $+1+$ & $+1+$ & $+1+$ \\
\hline G3 & $+1+$ & $-1-$ & $-1-$ & - & + & + & $+1+$ & $+1+$ & $+1+$ \\
\hline $\mathrm{G}^{\mathrm{e}}$ & $+1-$ & $-1-$ & $-1-$ & - & - & - & $+1+$ & $+1+$ & $+/+$ \\
\hline A2 & $+1-$ & $-1-$ & $-1-$ & + & - & + & $-1+$ & $+1+$ & $+1+$ \\
\hline $\mathrm{K} 1^{\mathrm{e}}$ & $+1+$ & $-1-$ & $-1-$ & - & - & + & $+1+$ & $+1+$ & $+1+$ \\
\hline L1 & $+1+$ & $-1+$ & $+1-$ & - & - & + & $-1+$ & $+1+$ & $+1+$ \\
\hline B3 & $+/ \mathrm{su}$ & $+/ \mathrm{su}$ & $-/ \mathrm{su}$ & + & + & + & $+1+$ & $+1+$ & $+1+$ \\
\hline K10 & $-1-$ & $+1-$ & $-1-$ & - & - & + & $+1+$ & $+1+$ & $+1+$ \\
\hline A3 & $+/ \mathrm{su}$ & $-/ \mathrm{su}$ & $-/ \mathrm{su}$ & + & + & + & $+1+$ & $+1+$ & $+1+$ \\
\hline B5 & $-1-$ & $-1-$ & $+1-$ & - & - & + & $+1+$ & $-1+$ & $+1+$ \\
\hline
\end{tabular}

a A.m, Anaplasma marginale.

b B.bo, Babesia bovis.

c B.bi, Babesia bigemina.

d su, serology unrealized.

e Calves that died.

\section{Discussion}

The region described in this study is characterized as an area of enzootic stability, with the presence of a high number of animals testing positive for TBD agents, and with chronically infected adults without the presence of clinical signs of disease.

The herd used in this study consisted of crossbred dairy cattle that maintain a genetic susceptibility to ticks, thus remaining chronically infected, which accounts for the high frequency of the detected vertical transmission. The cattle breeds, by virtue of their origin, react differently to tick infestations (Bock et al., 1997). Bos taurus indicus breeds have a higher genetic resistance to infestation by $R$. microplus, while B. t. taurus breeds are more susceptible (Brito et al., 2011). This genetic trait is transmitted to descendants, keeping a proportion of the blood lineage (Bock et al., 1997). This susceptibility can explain our results, as well as those of Bilhassi et al. (2014) who observed, through qPCR for B. bovis, the greatest parasitaemia in $B$. t. taurus animals relative to $B$. t. indicus and its crossbreds, and the results of Ribeiro et al. (1995) who observed low values of transplacental transmission of $B$. t. indicus in A. marginale.

In our study, a high transplacental transmission rate of $A$. marginale was observed. This result has been reported in most acute experimental infections (Zaugg, 1985; Ribeiro et al., 1995; Kessler, 2001), and also in naturally infected pregnant cows (Norton et al., 1983; Ribeiro et al., 1995; Maldonado et al., 2012; Grau et al., 2013; Silva et al., 2015). Prior studies have demonstrated that transmission occurs in the second and third trimesters of pregnancy (Zaugg and Kuttler, 1984; Zaugg, 1985; Potgieter and Van Rensburg, 1987; Ribeiro et al., 1995). However, in these studies, there is no evidence of a relationship between the time of transmission and foetus susceptibility.

Our results demonstrate the presence of $B$. bovis vertical transmission. Vertical transmission of $B$. bovis has mainly been described in individual reports of neonatal death and abortion cases (De Vos et al., 1976; Trueman and McLennan, 1987; Barbosa et al., 1994; Bracarense et al., 2001; Santarosa et al., 2013), and also in some studies with naturally infected asymptomatic cows (Osaki et al., 2002; Maldonado et al., 2012). Simultaneous infections with $A$. marginale and $B$. bovis were previously reported in bovine foetuses by Herrera et al. (1982), making ours the first study to describe coinfection in asymptomatic neonates, as well as the first report of triple co-infection.

The low transplacental transmission rates of $B$. bigemina corroborate the findings of Zolotareff (1936) and Roux (1939), cited by Neitz (1956) and Atwell (1975), which indicate how rare this form of transmission is for this parasite. The differences in transmission among $A$. marginale, $B$. bovis and $B$. bigemina in calves suggest that intrinsic characteristics of the parasite (e.g., its size, shape and strain) and its host (e.g., injury in the blood vessels of the placental membranes and immunity) might affect transmission capacity.

The serology and nPCR results observed in mothers and their calves, did not allow us to draw conclusions. However, by analysing some of the molecular parasite detection and serology results, we can presume that the calves with positive NPCR and negative serology may have recently acquired the infection, whereas animals with positive serology and nPCR could have had earlier infections, as well as animals positive only by serology and with negative nPCR results, which can be justified by extremely low parasitemia, or foetal infection control as proposed by Zaugg (1985).

The haematimetric parameters of the cows with positive and negative results were very similar, suggesting a control infection by the adult host, as shown in a sub-clinical course. The anaemia characterized by decreased packed cell volumes and haemoglobin concentrations observed in calves positive for haemoparasites has been previously reported (Dalgliesh et al., 1976; Sulaiman et al., 2010).

The fact that cows do not present clinical signs and have no laboratory changes, such as anaemia, at the time of delivery might explain in part the absence of miscarriages related to TBDs by virtue of hypoxia (Swift and Paumer, 1978). However, three calves died, and all of them had clinical and laboratory signs compatible with anaplasmosis, confirmed by nPCR. Two of these animals also had leptospiraemia, with a co-infection of A. marginale, BVDV and Leptospira sp., which may have acted synergistically to decrease the haematocrit levels and lead to death. The other calf had a presumptive diagnosis of fatal neonatal anaplasmosis

Previous reports of congenital and asymptomatic babesiosis (for B. bovis) and anaplasmosis (Fowler and Swift, 1975; Zaugg, 
1985; Osaki et al., 2002; Maldonado et al., 2012; Grau et al., 2013; Santarosa et al., 2013), or sick calves with anaplasmosis and babesiosis (De Vos et al., 1976; Paine and Miller, 1977; Norton et al., 1983; Passos and Lima, 1984; Barbosa et al., 1994; Bracarense et al., 2001; Yeruham et al., 2003) have been published. Thus, it is evident that this pathway is important in some regions (Silva et al., 2015) for the ease of transmission, and as a cause of economic loss that it might entail. These factors reinforce the hypothesis that congenital anaplasmosis and babesiosis could be the cause of many undiagnosed neonatal deaths of calves as suggested by Norton et al. (1983), and should be part of the differential diagnosis of neonatal deaths.

Prior discussions of the factors associated with transmission in reports of neonatal congenital death for anaplasmosis or babesiosis have been brief. Studies of anaplasmosis indicate that acute infections may cause the transmission (Zaugg and Kuttler, 1984), and suggest that transplacental transmission does not occur through parasitized erythrocytes, but through the active extra-erythrocyte phase of the parasite, which can be eliminated by the foetus inutero, except in situations where the parasite challenge is intense, in which case the foetus is unable to eradicate the infection, allowing the establishment of the intra-erythrocyte phase (Zaugg, 1985).

In this context, it is possible that the immunosuppressive factors that increase excessive challenges to foetuses or constant reinfection from cows are important, as described by Silva and Fonseca (2014), who reported that the transient immunosuppression that occurs in cows in the peripartum period is the reason for an increase of sub-clinical infections and possibly the cause of exacerbated vertical transmission. Moreover, Pypers et al. (2011) found a correlation between immunosuppression followed by the death of calves and a co-infection with BVDV. In our study, two of the calves that died were also positive for BVDV, which corroborates previous findings; however, one of the calves was negative in all of the differential diagnoses, which makes it plausible that only anaplasmosis may have caused the death of the calves.

The scenario above demonstrates the complexity of transplacental transmission and indicates the need for other studies of this subject, e.g., it is not known if chronically infected cows can transmit parasites in successive pregnancies. In our study, we could not identify a relationship between the age of the cow and transmission, as cows of different ages transmitted the parasites to their foetuses. Another point that we regard as important is whether the difference in virulence of parasite strains or if genetic variability may influence the transmission potential of infection and disease to the foetus because attenuated strains of $B$. bovis cause a reduced number of sequestered erythrocytes in the brain, as well as a reduction of parasite in the tissues, in relation to non-attenuated strains (Sondgeroth et al., 2013).

Finally, the observed transmissions of $A$. marginale, $B$. bovis and $B$. bigemina were associated with the presence of parasites in the blood, and the probable deaths by anaplasmosis demonstrate the importance of this infection pathway in the epidemiology of the agent. This pathway differs from that proposed by Zaugg (1985), which described the temporary intrauterine infection to $A$. marginale, which generated an immune response, and found that the new-born is a reservoir of infection. Thus, in an area of enzootic stability, it is necessary to characterize the parasite-vector-host equilibrium (Jonsson et al., 2012) because after the equilibrium is lost, transplacental transmission may be common, constituting an important mechanism for the dissemination of parasites in herds.

\section{References}

Ait-Hamou, S., Rahali, T., Sahibi, H., Belghyti, D., Losson, B., Goff, W., Rhalem, A., 2012. Molecular and serological prevalence of Anaplasma marginale in cattle of North Central Morocco. Res. Vet. Sci. 93, 1318-1323.
Amorim, L.S., Wenceslau, A.A., Carvalho, F.S., Carneiro, P.L.S., Albuquerque, G.R., 2014. Bovine babesiosis and anaplasmosis complex: diagnosis and evaluation of the risk factors from Bahia, Brazil. Rev. Bras. Parasitol. Vet. 23, 328-336.

Atif, F.A., Khan, M.S., Iqbal, H.J., Arshad, G.M., Ashraf, E., Ullah, S., 2012. Prevalence of Anaplasma marginale, Babesia bigemina and Theileria annulata infections among cattle in Sargodha District, Pakistan. Afr. J. Agric. Res. 7, 3302-3307.

Atwell, R.B., 1975. Prenatal Babesia bigemina infection in a calf. Aust. Vet. J. 51, 539 (Letter).

Aubry, P., Geale, D.W., 2011. Review of bovine anaplasmosis. Transbound. Emerg. Dis. 58, 1-30.

Baêta, B.A., Ribeiro, C.C., Teixeira, R.C., Cabezas-Cruz, A., Passos, L.M., Zweygarth, E. Fonseca, A.H., 2014. Characterization of two strains of Anaplasma marginale isolated from cattle in Rio de Janeiro, Brazil, after propagation in tick cell culture. Ticks Tick Borne Dis. 6, 141-145.

Barbosa, M.F.R., Costa, J.O., Tafuri, W.L., 1994. Transmissão congênita de Babesia bovis: relato de um caso autóctone em Minas Gerais - Brasil. Arq. Bras. Med. Vet. Zootec. 46, 519-526.

Barros, S.L., Madruga, C.R., Araújo, F.R., Menk, C.F., Almeida, M.A.O., Melo, E.P.S Kessler, R.H., 2005. Serological survey of Babesia bovis, Babesia bigemina, and Anaplasma marginale antibodies in cattle from the semi-arid region of the state of Bahia, Brazil, by enzyme-linked immunosorbent assays. Mem. Inst. Oswaldo Cruz 100, 613-617.

Bilhassi, T.B., Oliveira, H.N., Ibelli, A.M., Giglioti, R., Regitano, L.C., Oliveira-Sequeira, T.C., Bressani, F.A., Malagó Jr., W., Resende, F.D., Oliveira, M.C.S., 2014. Quantitative study of Babesia bovis infection in beef cattle from São Paulo state Brazil. Ticks Tick Borne Dis. 5, 234-238.

Bock, R.E., De Vos, A.D., Kingston, T.G., McLellan, D.J., 1997. Effect of breed of cattle on innate resistance to infection with Babesia bovis, B. bigemina and Anaplasma marginale. Aust. Vet. J. 75, 337-340.

Bock, R., Jackson, L., De Vos, A., Jorgensen, W., 2004. Babesiosis of cattle. Parasitology 129, 247-269.

Bracarense, A.P.F., Vidotto, O., Cruz, G.D., 2001. Transmissão congênita de Babesid bovis. Arq. Bras. Med. Vet. Zootec. 53, 479-481

Brito, L.G., Oliveira, M.C.S., Rocha, R.B., Silva-Netto, F.G., Marim, A.D., Souza, G.C.R., Vendrame, F.B., Moura, M.M., 2010. Anaplasma marginale infection in cattle from south-western Amazonia. Pesq. Vet. Bras. 30, 249-254.

Brito, L.G., Barbieri, F.S., Rocha, R.B., Oliveira, M., Ribeiro, E.S., 2011. Evaluation of the efficacy of acaricides used to control the cattle tick, Rhipicephalus microplus, in dairy herds raised in the Brazilian southwestern Amazon. Vet Med. Int. 2011, 1-6.

Brito, L.G., Rocha, R.B., Barbieri, F.D.S., Ribeiro, E.S., Vendrami, F.B., Souza, G.C., Giglioti, R., Regitano, L.C.A., Falcoski, T.O.R.S., Tizioto, P.C., Oliveira, M., 2013. Babesia bovis infection in cattle in the southwestern Brazilian Amazon. Ticks Tick Borne Dis. 4, 78-82.

Dalgliesh, R.J., Dimmock, C.K., Hill, M.W.M., Mellors, L.T., 1976. Babesia argentina: disseminated intravascular coagulation in acute infections in splenectomized calves. Exp. Parasitol. 40, 124-131.

De Vos, A.J., Imes, G.D., Cullen, J.S., 1976. Cerebral babesiosis in a new-born calf. Onderstepoort J. Vet. Res. 43, 75-78.

Echaide, S.T., Knowles, D.P., Mcguire, T.C., Palmer, G.H., Suarez, C.E., Mcelwain, T.F. 1998. Detection of cattle naturally infected with Anaplasma marginale in a region of endemicity by nested PCR and a competitive enzyme-linked immunosorbent assay using recombinant major surface protein 5. J. Clin. Microbiol. 36, 777-782.

Fowler, D., Swift, B.L., 1975. Abortion in cows inoculated with Anaplasma marginale. Theriogenology 4, 59-67.

Gohil, S., Herrmann, S., Günther, S., Cooke, B.M., 2013. Bovine babesiosis in the 21st century: advances in biology and functional genomics. Int. J. Parasitol. 43, $125-132$.

Grau, H.E.G., Cunha Filho, N.A., Pappen, F.G., Farias, N.A.R., 2013. Transplacental transmission of Anaplasma marginale in beef cattle chronically infected in southern Brazil. Rev. Bras. Parasitol. Vet. 22, 189-193.

Guglielmone, A.A., 1995. Epidemiology of babesiosis and anaplasmosis in South and Central America. Vet. Parasitol. 57, 109-119.

Herrera, I., Gonzales, M., Diaz, S., Moliner, J.L., Afonso, D.M., 1982. Hallazgos de Lemoparásitos em fetos bovinos. Rev. Cub. Cienc. Vet. 13, 87-88.

Jonsson, N.N., Bock, R.E., Jorgensen, W.K., Morton, J.M., Stear, M.J., 2012. Is endemic stability of tick-borne disease in cattle a useful concept? Trends Parasitol. 28, 85-89.

Kessler, R.H., 2001. Considerações sobre a transmissão de Anaplasma marginale. Pesq. Vet. Bras. 21, 177-179.

Kocan, K.M., De la Fluente, J., Guglielmone, A.A., Meléndez, R.D., 2003. Antigens and alternatives for control of Anaplasma marginale infection in cattle. Clin. Microbiol. Rev, 16, 698-712.

Kocan, K.M., De la Fluente, J., Blouin, E.F., Coetzee, J.F., Ewing, S.A., 2010. The natural history of Anaplasma marginale. Vet. Parasitol. 167, 95-107.

Kuttler, K.L., Marble, D.W., Matthews, N.J., 1962. Anaplasmosis complement-fixation responses in calves from anaplasmosis-infected dams. Am. J. Vet. Res. 23, 1007-1010.

Lew, A.E., Bock, R.E., Minchin, C.M., Masaka, S., 2002. A msp1 $\alpha$ polymerase chain reaction assay for specific detection and differentiation of Anaplasma marginale isolates. Vet. Microbiol. 86, 325-335.

Machado, R.Z., Montassier, H.J., Pinto, A.A., Lemos, E.G., Machado, M.R.F., Valadão, I.F.F., Barci, L.G., Malheiros, E.B., 1997. An enzyme-linked immunosorbent assay (ELISA) for the detection of antibodies against Babesia bovis in cattle. Vet. Parasitol. 71, 17-26. 
Maldonado, J., Coronado, A., Kowalski, A., Medina, J., 2012. Evidencia molecular de transmisión transplacentaria de Anaplasma marginale em becerros neonatos cebú de Venezuela. Zootec. Trop. 30, 109-114.

Ministério da Agricultura e Reforma Agrária, Brasil, 2010. Departamento Nacional de Meteorologia, Normais Climatológicas (1961-1999), Versão Revista e Ampliada, Brasília, INMET, 2010.

Mtshali, P.S., Tsotetsi, A.M., Thekisoe, M.M.O., Mtshali, M.S., 2013. Nested PCR detection and phylogenetic analysis of Babesia bovis and Babesia bigemina in cattle from peri-urban localities in Gauteng Province, South Africa. J. Vet. Med Sci. 76, 145.

Neitz, W.O., 1956. Classification, transmission and biology of piroplasms of domestic animals. Ann. N. Y. Acad. Sci. 64, 56-111.

Norton, J.H., Parker, R.J., Forbes-Faulkner, J.C., 1983. Neonatal anaplasmosis in a calf. Aust. Vet. J. 60, 348.

Osaki, S.C., Vidotto, O., Marana, E., Vidotto, M., Yoshihara, F., Pacheco, R., Igarashi, M., Minho, A., 2002. Ocorrência de anticorpos anti Babesia bovis e estudo sobre a infecção natural em bovinos da raça nelore, na região de Umuarama, Paraná, Brasil. Rev. Bras. Parasitol. Vet. 11, 77-83.

Paine, G.D., Miller, A.S., 1977. Anaplasmosis in a newborn calf. Vet. Rec. 15, 58

Passos, L.M.F., Lima, J.D., 1984. Diagnóstico de anaplasmose bovina congênita em Minas Gerais. Arq. Bras. Med. Vet. Zootec. 36, 743-744.

Perino, L.J., Sutherland, R.L., Woollen, N.E., 1993. Serum $\gamma$-glutamyltransferase activity and protein concentration at birth and after suckling in calves with adequate and inadequate passive transfer of immunoglobulin G. Am. J. Vet. Res. 54, 56-59.

Piercy, P., 1956. Transmission of anaplasmosis. Ann. N. Y. Acad. Sci. 64, 40-48.

Potgieter, F.T., Van Rensburg, L., 1987. The persistence of colostral Anaplasma antibodies and incidence of in utero transmission of Anaplasma infection in calves under laboratory condition. Onderstepoort J. Vet. Res. 54, 557-560.

Pypers, A.R., Holm, D.E., Williams, J.H., 2011. Fatal congenital anaplasmosis associated with bovine viral diarrhoea virus (BVDV) infection in crossbred calf. J. S. Afr. Vet. Assoc. 82, 179-182.

Reinbold, J.B., Coetzee, J.F., Hollis, L.C., Nickell, J.S., Riegel, C.M., Christopher, J.A., Ganta, R.R., 2010. Comparison of iatrogenic transmission of Anaplasma marginale in Holstein steers via needle and needle-free injection techniques. Am. J. Vet. Res. 71, 1178-1188.

Ribeiro, M.F.B., Lima, J.D., Guimarães, A.M., Scatamburlo, M.A., Martins, N.E., 1995 Transmissão congênita da anaplasmose bovina. Arq. Bras. Med. Vet. Zootec. 47 297-304.

Santarosa, B.P., Dantas, G.N., Ferreira, D.O.L., Rocha, N.S., Gonçalves, R.C., Amorim, R.M., Chiacchio, S.B., 2013. Infecção neurológica por Babesia bovis em bovino neonato - relato de caso. Vet. Zootec. 20, 447-452.

Shebish, E., Vemulapalli, R., Oseto, C., 2012. Prevalence and molecular detection of Anaplasma marginale, Babesia bovis and Babesia bigemina in cattle from Puntarenas Province, Costa Rica. Vet. Parasitol. 188, 164-167.
Sondgeroth, K.S., McElwain, T.F., Allen, A.J., Chen, A.V., Lau, A.O., 2013. Loss of neurovirulence is associated with reduction of cerebral capillary sequestration during acute Babesia bovis infection. Parasit. Vectors 6 , 181.

Silva, J.B., Fonseca, A.H., 2014. Risk factors for anaplasmosis in dairy cows during the paripartum. Trop. Anim. Health Prod. 46, 461-465

Silva, J.B., Castro, G.N.S., Fonseca, A.H., 2014. Longitudinal study of risk factors for anaplasmosis and transplacental transmission in herd cattle. Semina: Ci. Agrárias. 35, 2491-2500.

Silva, J.B., Gonçalves, L.R., Varani, A.M., André, M.R., Machado, R.Z., 2015. Genetic diversity and molecular phylogeny of Anaplasma marginale studied longitudinally under natural transmission conditions in Rio de Janeiro, Brazil. Ticks Tick Borne Dis. 6, 499-507.

Suarez, C.E., Palmer, C.H., Jasmer, D.P., Hines, S.A., Perryman, L.E., McElwain, T.F., 1991. Characterization of the gene encoding a 60-kilodalton Babesia bovis merozoite protein with conserved and surface exposed epitopes. Mol. Biochem. Parasitol. 46, 45-52.

Sulaiman, E.G., Arslan, S.H., Al-Obaidi, Q.T., Daham, E., 2010. Clinical, haematological and biochemical studies of babesiosis in native goats in Mosul. Iraqi J. Vet. Sci. 24, 31-35.

Swift, B.L., Paumer, R.J., 1976. Vertical transmission of Anaplasma marginale in cattle. Theriogenology 6, 515-521.

Swift, B.L., Paumer, R.J., 1978. Bovine fetal anoxia observed in pregnant beef heifers experimentally inoculated with Anaplasma marginale. Theriogenology 10 , 395-403.

Tembue, A.A.M., Silva, J.B., Silva, F.J.M., Pires, M.S., Baldani, C.D., Soares, C.O. Massard, C.L., Fonseca, A.H., 2011. Seroprevalence of IgG antibodies against Anaplasma marginale in cattle from south Mozambique. Rev. Bras. Parasitol. Vet. 20, 318-324.

Terkawi, M.A., Huyen, N.X., Shinuo, C., Inpankaew, T., Maklon, K., Aboulaila, M., Ueno, A., Goo, Y.K., Yokoyama, N., Jittapalapong, S., Xuan, X., Igarashi, I., 2011 Molecular and serological prevalence of Babesia bovis and Babesia bigemina in water buffaloes in the northeast region of Thailand. Vet. Parasitol. 178, 201-207.

Trueman, K.F., McLennan, M.W., 1987. Bovine abortion due to prenatal Babesia bovis infection. Aust. Vet. J. 64, 63.

Yeruham, I., Avidar, Y., Aroch, I., Hadani, A., 2003. Intra-uterine infection with Babesia bovis in a 2-day-old Calf. J. Vet. Med. 50, 60-62.

Zaugg, J.L., 1985. Bovine anaplasmosis: transplacental transmission as it relates to stage of gestation. Am. J. Vet. Res. 46, 570-572.

Zaugg, J.L., Kuttler, K.L., 1984. Bovine anaplasmosis: in utero transmission and the immunologic significance of ingested colostral antibodies. Am. J. Vet. Res. 45 440-443. 